\title{
MODEL PEMBELAJARAN PROBLEM BASED LEARNING (PBL) BERBANTUAN LKS KREASI SISTEM RESPIRASI UNTUK MENINGKATKAN HASIL BELAJAR SISWA SMA
}

\author{
Sri Mulyani Endang Susilowati \\ nanik_es@mail.unnes.ac.id \\ Jurusan Biologi \\ FMIPA - Universitas Negeri Semarang \\ Abadia Delima \\ abadiadelima@gmail.com \\ Jurusan Biologi \\ FMIPA - Universitas Negeri Semarang \\ Priyantini Widiyaningrum \\ wiwiedeka@mail.unnes.ac.id \\ Jurusan Biologi \\ FMIPA Universitas Negeri Semarang
}

\begin{abstract}
This study aims to determine the effect of Problem Based Learning (PBL) model aided LKS Creation Respiratory System to student learning outcomes MAN 1 Magelang. This study uses a quasi-experimental design. The sample used is a class XI MIA 6 as control class and XI MIA 5 as experimental class. Sampling technique using cluster random sampling. The results showed that the average cognitive achievement, experimental class is better than the control class, namely 66.97>58.70. Based on data analysis psychomotor learning outcomes, the experimental class get better results than the control class, is $76.67 \%$. On the affective aspects in the experimental group also showed better results is $79.99 \%$ while the control group is $62.32 \%$ with both good category. Both classes have reached school classical completeness is $\geq$ $75 \%$. Classical completeness experimental group reached $81.25 \%$, while the control group $75 \%$. The average yield of $91.5 \%$ the teacher's performance is very good. In general, teachers and students also respond very well to applied learning. Conclusions from this research is a model of PBL aided the Respiratory System LKS Creation a positive effect on learning outcomes of students of class XI MIA MAN 1 Magelang the academic year 2015/2016.
\end{abstract}

Keywords: Learning result; LKS Creation; PBL; Respiratory System

\section{PENDAHULUAN}

Pembelajaran adalah suatu proses yang rumit karena tidak sekedar menyerap informasi dari guru tetapi melibatkan berbagai kegiatan dan tindakan yang harus dilakukan untuk mendapatkan hasil belajar yang lebih baik. Menurut Endarwati (2011) bahwa yang melandasi proses pembelajaran meliputi: pertama, pembelajaran bertujuan memberikan bantuan agar belajar siswa menjadi efektif dan efisien. Kedua, pembelajaran bersifat terprogram. Ketiga, pembelajaran dirancang melalui pendekatan sistem. Keempat, pembelajaran dirancang berdasarkan pengetahuan tentang teori belajar.

Dalam sebuah pembelajaran, tugas guru yang paling utama adalah mengkondisikan lingkungan agar menunjang terjadinya 
perubahan perilaku yang lebih baik bagi siswa. Pembelajaran yang baik dan tepat akan memberikan kontribusi yang baik pula bagi siswa. Sebaliknya, pembelajaran yang dilaksanakan dengan tidak/kurang baik akan menyebabkan sulitnya mengembangkan potensi yang dimiliki siswa (Munandar, 2007). Kebanyakan yang terjadi adalah guru mengajar kurang bervariasi dalam menerapkan model atau strategi pembelajaran.

Menurut pendapat Muhson (2009) jika siswa berusaha sendiri untuk mencari pemecahan masalah serta pengetahuan yang menyertainya, akan menghasilkan pengetahuan yang benar-benar bermakna. Berdasarkan hasil wawancara dengan guru biologi kelas XI MAN 1 Magelang, diperoleh informasi bahwa pada saat pembelajaran siswa masih tergolong pasif pada saat diskusi. Siswa juga masih mengalami kesulitan dalam memahami konsep biologi, Hal tersebut terlihat dalam nilai Ujian Nasional tahun 2013/2014 belum sesuai dengan nilai yang diharapkan. Jurusan Ilmu Pengetahuan Alam sebanyak 160 siswa memiliki rata-rata nilai Ujian Nasional mata pelajaran biologi 56. Selain dari hasil belajar yang rendah, siswa juga masih kesulitan dalam menganalisis suatu permasalahan ketika diskusi.

Menurut Purnamaningrum (2012), Problem Based Learning merupakan pembelajaran yang dilakukan dengan menghadapkan siswa pada permasalahan yang nyata dalam konteks kehidupan seharihari. Siswa dapat menyusun pengetahuannya sendiri dalam memecahkan masalah dan mengupayakan berbagai macam solusinya yang mendorong siswa untuk berpikir kreatif.

Problem Based Learning dipilih karena dalam pelaksanaannya dapat mengakomodasi siswa untuk memberdayakan keterampilan berpikir kreatifnya. Model pembelajaran ini tampaknya dapat diterapkan dalam pembelajaran biologi untuk mencapai tujuan belajar dan mengetahui serta melatih berpikir kritis siswa (Purnamaningrum, 2012). Selain itu, PBL memiliki karakteristik yaitu mengajukan pertanyaan atau masalah yang terkait kehidupan nyata dan kerja sama dalam melakukan penyelidikan (Arnyana, 2005). Dari karakterisitik yang ada, maka model pembelajaran PBL ini sesuai jika diterapkan di sekolah yang masih minim menerapkan metode diskusi studi kasus.

Hasil wawancara dengan siswa MAN 1 Magelang diketahui bahwa salah satu materi biologi kelas XI yang tergolong sulit adalah sistem respirasi. LKS yang digunakan sebagai pembelajaran saat ini adalah LKS yang dikeluarkan oleh penerbit. LKS tersebut hanya berisi uraian materi dan soal-soal sehingga siswa belum bisa menghubungkan materi dengan permasalahan di kehidupan sehari-hari. Namun sebagian yang dibahas dalam materi ini cukup sulit untuk dipahami Karena mengandung banyak unsur mengingat atau menghafal. Untuk itu, perlunya suatu lembar kerja siswa (LKS) sebagai pedoman yang dapat menuntun siswa untuk belajar dengan baik dan mampu menjawab setiap permasalahan yang disajikan (Prastowo, 2011).

Menurut Damayanti (2012), LKS yaitu materi ajar yang sudah dikemas sedemikian rupa sehingga siswa diharapkan dapat mempelajari secara mandiri. Dalam penelitian ini, LKS Kreasi (Kreatif Belajar Sistem Respirasi) dikemas berbeda dibandingkan dengan LKS lainnya. Keunggulan dari LKS ini antara lain desainnya dibuat lebih menarik sehingga tidak membuat siswa merasa bosan, dilengkapi dengan petunjuk pelaksanaan 
praktikum yang jelas, dan menyajikan beragam studi kasus masalah terkini.

Berdasarkan uraian tersebut pentingnya diterapkan model pembelajaran yang mampu merangsang siswa berpikir kritis, aktif, dan mampu memecahkan setiap permasalahan yang diberikan. PBL yang dibantu dengan LKS Kreasi merupakan salah satu model yang sangat selaras dengan materi sistem respirasi. Karena dengan adanya kombinasi tersebut dapat meningkatkan hasil belajar siswa dan melatih kemampuan siswa untuk berpikir kritis. Penelitian ini bertujuan untuk mengetahui pengaruh penerapan model PBL berbantuan LKS Kreasi materi sistem respirasi terhadap hasil belajar siswa Kelas XI MIA MAN 1 Magelang.

\section{KAJIAN PUSTAKA}

Model pembelajaran PBL merupakan inovasi pembelajaran yang membantu guru menciptakan lingkungan pembelajaran yang dimulai dengan masalah yang penting dan relevan bagi siswa, sehingga memungkinkan siswa memperoleh pengalaman belajar yang nyata. Dalam pembelajaran ini siswa terlibat secara aktif, kolaboratif, pembelajaran berpusat kepada siswa, yang mengembangkan kemampuan pemecahan masalah dan kemampuan belajar mandiri yang diperlukan untuk menghadapi tantangan dalam kehidupan dan karier, dalam lingkungan yang semakin kompleks sekarang ini. PBL dilakukan dengan kerja kelompok antar siswa. Siswa menyelidiki sendiri, menemukan permasalahan, kemudian menyelesaikan masalahnya di bawah petunjuk fasilitator (guru).

Menurut Sanjaya (2007) langkahlangkah PBL dimulai dengan: (1) kesadaran adanya masalah yang harus dipecahkan. Siswa harus dapat menemukan adanya kesenjangan yang terjadi dari berbagai fenomena. Guru mengarahkan siswa untuk menentukan satu atau dua kesenjangan yang perlu dikaji oleh kelompok. (2) Merumuskan masalah: ini sangat penting untuk kejelasan dan persamaan persepsi tentang masalah dan berkaitan dengan jenis data yang harus dikumpulkan. (3) Merumuskan hipotesis: merupakan langkah penting yang harus dilakukan. Kemampuan merumuskan hipotesis berarti mampu menentukan berbagai kemungkinan penyelesaian masalah. (4) Mengumpulkan data: siswa mampu mengumpulkan, memilah, kemudian memetakan dan menyajikan data dalam berbagai tampilan sehingga mudah dipahami. (5) Menguji hipotesis: siswa dapat menentukan hipotesis yang diterima dan yang ditolak. Dalam tahap ini diharapkan siswa mampu menelaah data dan membahasnya untuk melihat hubungannya dengan masalah yang dikaji. Diharapkan siswa dapat mengambil keputusan dan kesimpulan.

\section{METODE PENELITIAN}

Penelitian dilaksanakan pada semester genap tahun pelajaran 2015/2016. Desain yang digunakan dalam penelitian ini adalah quasi experimental dengan rancangan penelitian nonequivalent kontrol group design. Populasi terdiri atas 6 kelas yaitu kelas XI MIA 1 - XI MIA 6 MAN 1 Magelang. Penentuan sampel menggunakan teknik cluster random sampling. Sampel yang digunakan dua kelas, yaitu satu kelas eksperimen, Kelas XI MIA 5 terdiri atas 38 siswa dan satu kelas kontrol, kelas XI MIA 6 terdiri atas 34 siswa. Data dikumpulkan dengan metode observasi dan metode tes. Metode observasi digunakan untuk menilai sikap dan psikomotorik siswa selama proses pembelajaran. Metode tes digunakan untuk mengukur hasil belajar kognitif siswa pada materi sistem respirasi menggunakan soal 
multiple choice. Soal tes telah diuji validitas, reliabilitas, tingkat kesukaran dan daya pembeda soal. Untuk menguji reliabilitas soal menggunakan rumus KR 21 diperoleh harga $r$ $=0,69$ berarti reliabilitasnya tinggi. Soal tes diberikan di awal sebagai pretest dan di akhir pertemuan sebagai posttest. Pembelajaran dilakukan pada kelas eksperimen sesuai dengan sintaks model pembelajaran PBL menggunakan LKS Kreasi (Kreatif Belajar Sistem Respirasi).

Penilaian hasil belajar kognitif diperoleh dari nilai post test siswa. Aspek psikomotorik diperoleh dari hasil observasi keterampilan siswa saat praktikum dan membuat laporan. Sedangkan aspek afektif diperoleh dari hasil observasi sikap saat diskusi dan presentasi.

Data penelitian berupa hasil belajar kognitif dianalisis menggunakan statistic, uji t. Untuk menguji hipotesis, ada perbedaan yang signifikan antara hasil belajar kognitif kelas eksperimen dengan kelas control menggunakan uji t dengan $\alpha=0,05$. Sebelum dilakukan uji t dilakukan uji normalitas dan homogenitas data. Uji normalitas menggunakan chi kuadrat $\left(\chi^{2}\right)$ dan uji homogenitas menggunakan uji Bartlett. Data hasil belajar psikomotorik, dan afektif dianalisis secara deskriptif kuantitatif. Sedangkan untuk data penunjang berupa tanggapan siswa dan guru juga dianalisis secara deskriptif persentatif.

\section{HASIL DAN PEMBAHASAN}

Penelitian telah dilaksanakan pada kelas XI MIA 5 sebagai kelas eksperimen, yakni kelas yang dikenai model pembelajaran PBL berbantuan LKS Kreasi. Kelas XI MIA 6 sebagai kelas kontrol, dikenai model pembelajaran menggunakan metode ceramah yaitu diskusi dan presentasi. Hasil penelitian terdiri dari dua macam data yaitu data pokok dan data penunjang. Hasil belajar siswa disajikan dalam Tabel 1.

Tabel 1. Hasil belajar Kelas XI MAN 1 Magelang Semester Genap Tahun Ajaran 2015/2016

\begin{tabular}{|c|c|c|c|c|c|c|}
\hline \multirow{3}{*}{ Kelas } & \multicolumn{6}{|c|}{ Rata-rata Hasil Belajar } \\
\hline & \multicolumn{4}{|c|}{ Kognitif } & \multirow{2}{*}{ Afektif (\%) } & \multirow{2}{*}{$\begin{array}{l}\text { Psikomotorik } \\
(\%)\end{array}$} \\
\hline & Pre test & Post test & LKS & Laporan & & \\
\hline Eksperimen (XI MIA 5) & 51,5 & 66,97 & 82,85 & 77,47 & $\begin{array}{l}79,99 \\
\text { (baik) }\end{array}$ & 76,67 (baik) \\
\hline Kontrol (XI MIA 6) & 50,91 & 58,70 & 76,29 & 75,08 & $\begin{array}{l}62,32 \\
\text { (baik) }\end{array}$ & 69,44 (baik) \\
\hline
\end{tabular}

\section{Hasil Belajar Kognitif Siswa}

Data pokok berupa hasil belajar kognitif berupa pos test, data hasil belajar afektif, dan psikomotorik. Data penunjang berupa tanggapan siswa dan guru. Pembelajaran dengan menerapkan model pembelajaran PBL berbantuan LKS Kreasi merupakan variasi pembelajaran yang memberikan kesempatan kepada siswa untuk mempresentasikan solusisolusi yang mereka kemukakan. LKS Kreasi yang menjadi pedoman belajar siswa sangat membantu mereka dalam menganalisis masalah dan melatih siswa berpikir kritis. Hasil belajar kognitif siswa diperoleh dari nilai post test materi sistem respirasi di akhir pembelajaran.

Hasil belajar kognitif siswa pada kelas eksperimen lebih baik dibandingkan kelas kontrol. Hal ini dapat dilihat pada Tabel 2 yang menunjukkan bahwa rata-rata nilai hasil belajar siswa pada kelas eksperimen adalah 66,97 dan pada kelas kontrol 58,70. Hasil post test pada kelas eksperimen, siswa yang telah mencapai nilai KKM (Kriteria Ketuntasan Minimal) sebanyak 31 orang artinya ketun- 
tasan klasikal kelas sebesar 81,5\%. Sedangkan pada kelas kontrol ketuntasan klasikalnya hanya $75 \%$. Pembelajaran dengan menggunakan model PBL berbantuan LKS Kreasi memberikan dampak positif terhadap hasil belajar siswa. Hal tersebut sesuai dengan penelitian Manahal, et al (2007) yang menyatakan bahwa PBL dapat memotivasi siswa untuk melakukan investigasi pemecahan masalah pada kehidupan nyata.

Pembelajaran dengan menggunakan model pembelajaran yang menarik dan menyenangkan lebih mudah membuat siswa menangkap isi materi yang dipelajari. Ketika menyampaikan materi, gurupun tak lupa untuk menyampaikan apersepsi sehingga membuat siswa tertarik mengikuti pembelajaran. Selain hasil belajar meningkat, kemampuan menganalisis masalah pun sudah baik, hal tersebut sejalan dengan penelitian Sandra, et al tahun 2012.

Pembelajaran yang diterapkan sudah memenuhi karakteristik dari pembelajaran PBL. Pendapat I Wayan Dasna dan Sutrisno yang dikutip oleh Faturrohman (2008) menyatakan bahwa PBL mempunyai karakteristik sebagai berikut; 1) Belajar diawali dengan masalah, 2) Masalah yang diberikan berhubungan dengan dunia nyata siswa, 3) Mengorganisasikan pelajaran seputar masalah, 4) Siswa diberikan tanggung jawab yang besar untuk melakukan proses belajar secara mandiri, 5) Menggunakan kelompok kecil, dan 6) Siswa dituntut untuk mendemonstrasikan apa yang telah dipelajari dalam bentuk kinerja. Hal tersebut melatih kerja sama antar siswa untuk saling berdiskusi dan memecahkan masalah yang diberikan.

Kelas kontrol juga menunjukkan hasil yang sudah baik, namun masih terbilang lebih rendah jika dibandingkan dengan kelas eksperimen. Namun, hasil post test yang telah diujikan mengalami peningkatan dari sebelumnya. Selain itu, pemberian LDS dengan diberikan kasus-kasus yang relevan dengan materi cukup merangsang pemahaman siswa untuk memecahkan masalah. Kemampuan menjawab setiap masalah yang disajikan juga cukup baik. Siswa masih berusaha untuk memecahkan masalah bersama dengan kelompoknya meskipun jawaban yang didapat belum selengkap pada kelas eksperimen.

Pembelajaran pada kelas eksperimen dan kontrol dari pertemuan pertama sampai terakhir menunjukkan peningkatan namun kelas eksperimen lebih baik daripada kelas kontrol. Artinya pada kelas eksperimen PBL membantu siswa untuk memahami hakekat belajar sebagai cara berfikir bukan hanya sekedar mengerti pembelajaran oleh guru berdasarkan buku teks. Faktor yang menyebabkan hasil belajar kelas kontrol rendah antara lain proses pembelajaran yang lebih banyak menggunakan metode ceramah di depan kelas dan LDS saja. Lembar diskusi siswa yang diberikan tidak banyak menampilkan gambar, penugasan, dan lebih sedikit studi kasusnya. Hal tersebut menjadikan siswa kurang tertarik belajar materi sistem respirasi dan kurang berkembang dalam menyelesaikan masalah yang disajikan. Berikut ini pada Tabel 2 disajikan rata-rata hasil belajar kognitif kelas eksperimen dan kelas kontrol.

Secara umum pembelajaran berdasarkan masalah menyajikan kepada siswa situasi masalah yang autentik dan bermakna yang dapat memberikan kemudahan kepada mereka untuk melakukan penyelidikan dan inkuiri. Pembelajaran lebih berorientasi pada aktivitas siswa untuk memperoleh hasil belajar berupa 
perpaduan antara aspek kognitif, afektif, dan psikomotorik secara proposional.

Tabel 2. Rata-rata Hasil Belajar Kognitif Kelas Eksperimen dan Kelas Kontrol

\begin{tabular}{cccccc}
\hline \multirow{2}{*}{ Kelas } & \multicolumn{3}{c}{ Rata-rata Hasil Belajar Kognitif } & Ketuntasan Klasikal \\
\cline { 2 - 4 } & Pretest & Post test & LKS & Laporan & $(\%)$ \\
\hline XI MIA 5 (eksp) & 51,5 & 66,9 & 82,8 & 77,4 & 81,5 \\
XI MIA 6 (control) & 50,9 & 58,7 & 76,2 & 75,0 & 75 \\
\hline
\end{tabular}

Keaktifan siswa ada yang secara langsung dapat diamati dan ada yang tidak, seperti mengerjakan tugas, berdiskusi, dan mengumpulkan data. Kadar keaktifan siswa tidak hanya ditentukan oleh aktivitas fisik semata, tetapi juga oleh aktivitas nonfisik seperti mental, intelektual, dan emosional (Widodo danWidayanti, 2013).

Berdasarkan perhitungan diperoleh nilai $t_{\text {hitung }}=4,67$ sedangkan $t_{\text {tabel }}=2,01$, jadi $t_{\text {hitung }}>$ $\mathrm{t}$ tabel sehingga $\mathrm{H}_{0}$ ditolak. Dapat disimpulkan bahwa terdapat perbedaan yang signifikan antara nilai pada pembelajaran menggunakan model PBL berbantuan LKS Kreasi dengan metode ceramah. Dengan melihat nilai ratarata kedua kelas tersebut dapat kita lihat nilai post test pada pembelajaran kelas eksperimen lebih besar daripada kelas kontrol. Maka pembelajaran dengan menerapkan model PBL berbantuan LKS Kreasi lebih efektif digunakan di MAN 1 Magelang.

\section{Hasil Belajar Afektif Siswa}

Pada umumnya secara teori-teori dan konsep, LKS biologi hanya berisikan teks tertulis saja. Hal tersebut cenderung membuat siswa bosan dan jenuh dalam belajar. Maka dari itu dengan diberikannya alternatif baru melalui LKS Kreasi, siswa menjadi tertarik belajar dan berdiskusi apalagi desain yang dibuat berbeda. Kemampuan siswa dalam menjawab dan menyelesaikan masalah pun menjadi terpacu lebih meningkat. Hal tersebut dapat terlihat pada Tabel 3 yang menyajikan rata-rata hasil belajar afektif siswa saat diskusi dan presentasi.

Kemampuan siswa dalam berdiskusi bersama kelompoknya menunjukkan perubahan yang baik karena permasalahan yang diberikan mampu merangsang daya berpikir siswa. Kasus-kasus yang disajikan juga sangat mendukung pemahaman siswa karena berkaitan dengan informasi masa kini. Selain itu, dilengkapi dengan gambar yang detail dan jelas dalam membantu pemahaman siswa.

Tabel 3. Data Hasil Belajar Afektif Kelas XI MAN 1 Magelang

\begin{tabular}{lccc}
\hline \multicolumn{1}{c}{ Kelas } & \multicolumn{2}{c}{ Rata-rata Hasil Belajar Afektif } & Rata-rata (\%) \\
\cline { 2 - 4 } & Diskusi \%) & Presentasi (\%) \\
\hline XI MIA 5 (eksp) & 82,01 & 77,97 & 79,99 (baik) \\
XI MIA 6 (control) & 60,06 & 64,59 & 62,32 (baik) \\
\hline
\end{tabular}

Tingkat keberhasilan yang dapat dicapai oleh seorang siswa dilihat berdasarkan pengalaman yang diperoleh setelah dilakukan evaluasi berupa tes. Tes tersebut diwujudkan dengan nilai atau angka-angka tertentu serta menyebabkan terjadinya perubahan kognitif, afektif, maupun psikomotorik (Wulandari,
2013). Siswa yang mendapatkan perlakuan menggunakan model pembelajaran PBL mengalami peningkatan hasil belajar baik pada ranah kognitif, afektif, dan psikomotorik. Dengan model pembelajaran PBL, siswa dapat belajar secara maksimal dengan difasilitasi oleh LKS Kreasi. Sikap yang 
ditunjukkan siswa ketika diskusi dan presentasi setiap minggunya, menunjukkan perkembangannya yang semakin baik.

Rata-rata hasil belajar afektif saat pelaksanaan diskusi dan presentasi menunjukkan hasil yang baik pula bagi kelas kontrol. Presentase untuk aspek afektif pada saat diskusi dan presentasi masing-masing 60,06\% dan $64,59 \%$. Hasil tersebut lebih rendah jika dibandingkan dengan kelas eksperimen. Salah satu faktor yang mempengaruhi perbedaan tersebut adalah penggunaan LDS yang belum banyak menyajikan kasus, sehingga kemampuan siswa dalam berdiskusi kurang berkembang. Selain itu, dilihat dari kondisi kelasnya yang ramai membuat kegiatan presentasi kurang berjalan dengan baik karena waktu yang banyak terbuang.

Kondisi kelas yang ramai di kelas kontrol diartikan sebagai siswa yang sulit diatur ketika pembelajaran berlangsung dan suka bergurau jika diberi penjelasan oleh guru. Berbeda halnya dengan kelas eksperimen yang ramai karena siswa aktif ketika diskusi dan presentasi berjalan.

\section{Hasil Belajar Psikomotorik Siswa}

Selain hasil belajar kognitif dan afektif, hasil belajar psikomotorik juga dapat mendorong siswa terhadap hasil belajar

Tabel 4. Data Hasil Belajar Psikomotorik Kelas XI MAN 1 Magelang

\begin{tabular}{ccc}
\hline Kelas & Jumlah (orang) & Rata-rata Hasil Belajar Psikomotorik (\%) \\
\hline XI MIA 5 & 38 & 76,67 (baik) \\
XI MIA 6 & 34 & 69,44 (baik) \\
\hline
\end{tabular}

Pada kelas kontrol, keterampilan siswa saat melakukan praktikum dari mulai menyiapkan alat dan bahan, mengoperasikan alat, melakukan eksperimen, sampai dengan menyusun laporan praktikum masih belum terlihat. Siswa cenderung masih bersikap acuh terhadap pembagian tugas yang didapat, namun tetap memperhatikan prosedur kerja. selama proses belajar mengajar di dalam kelas. Ranah psikomotorik berkenaan dengan hasil belajar kemampuan bertindak selama proses di dalam kelas (Putri, et al 2015). Keterampilan siswa dalam melakukan suatu tindakan psikomotor dapat mempengaruhi nilai yang mereka capai.

Hasil penelitian ini menunjukkan hasil belajar psikomotorik kelas eksperimen lebih tinggi daripada kelas kontrol. Hal tersebut dapat dilihat pada Tabel 4 terkait data hasil belajar psikomotorik kelas XI MAN 1 Magelang. Aspek-aspek yang dikategorikan dalam kriteria penilaian psikomotorik saat praktikum berlangsung antara lain: menyiapkan alat dan bahan, keterampilan menggunakan alat, melakukan eksperimen, sampai dengan menyusun laporan praktikum. Hasil belajar kognitif, afektif, dan psikomotorik dapat menjadi acuan utama atau keberhasilan dari hasil belajar siswa selama proses belajar mengajar. Hal tersebut karena menuntut siswa untuk lebih aktif dalam melaksanakan kegiatan pembelajaran serta berperan aktif dalam melakukan keterampilan utamanya.
Jika dilihat dari rata-rata hasil belajar psikomotorik sudah menunjukkan hasil baik. Hal tersebut didukung dengan pemberian praktikum yang baru sehingga memicu siswa untuk semangat dalam melaksanakan eksperimen. Kendala yang ditemui juga didapat dari nilai laporan praktikum siswa. Siswa banyak yang belum mengetahui langkah-langkah 
penyusunan laporan sehingga hal itu menjadi hambatan siswa sendiri dalam menyelesaikan tugas dengan baik. Pada saat diberi penjelasan mengenai format penyusunan laporan, siswa menjawab paham akan tugasnya. Namun ketika laporan dikumpulkan, pekerjaan siswa masih banyak yang belum lengkap.

\section{Hasil Angket Tanggapan Siswa}

Tanggapan siswa terhadap pembelajaran yang telah dilakukan dengan menggunakan model pembelajaran PBL berbantuan LKS Kreasi pada kelas eksperimen diukur dengan menggunakan angket. Berdasarkan perhitungan analisis data, pendapat siswa mengenai model pembelajaran yang digunakan bersifat positif, dengan presentase tanggapan siswa sebesar $85,83 \%$ secara keseluruhan.
Siswa beranggapan bahwa model pembelajaran PBL mampu menjadi alternatif untuk mengatasi strategi pembelajaran yang monoton dan kurang bervariasi. Guru di depan kelas bertindak sebagai fasilitator, berperan untuk menyimpulkan dan mengklarifikasi di akhir pembelajaran sehingga pembelajaran langsung berpusat pada siswa. Studi kasus yang disajikan di dalam LKS Kreasi juga mampu membantu pemahaman siswa untuk berpikir kritis memecahkan masalah bersama dengan kelompoknya. Selanjutnya hasilnya disampaikan di depan kelas, ditanggapi oleh kelompok lain, dan guru mengklarifikasi jika ada kesalahan konsep. Persentase tiap aspek tanggapan siswa dapat dilihat pada Tabel 5 berikut ini.

Tabel 5. Presentase Angket Tanggapan Siswa terhadap Pembelajaran dengan Model PBL Berbantuan LKS Kreasi

\begin{tabular}{clcc}
\hline No. & \multicolumn{1}{c}{ Aspek } & Presentase (\%) & Keterangan \\
\hline 1. & Suasana belajar menyenangkan dan menantang & 93,05 & Sangat baik \\
2. & Materi sistem respirasi lebih mudah dipahami & 86,11 & Sangat baik \\
3. & PBL berbantuan LKS Kreasi meningkatkan minat & 86,11 & Sangat baik \\
& belajar & & \\
4. & LKS Kreasi memicu berpikir kritis dalam pemecahan & 85,41 & Sangat baik \\
& masalah. & & \\
5. & Nyaman dengan kegiatan studi kasus selama diskusi & 86,11 & Sangat baik \\
6. & Pemutaran video memperkuat ingatan & 86,11 & Sangat baik \\
7. & Mudah terangsang berpikir kritis dalam memecahkan & 81,25 & Sangat baik \\
& masalah & & \\
8. & Mudah memecahkan masalah dengan bantuan LKS & 81,94 & Sangat baik \\
& Kreasi & 82,63 & Sangat baik \\
9. & Lebih mudah dan berani mengungkapkan ide & 89,58 & Sangat baik \\
10. & PBL berbantuan LKS Kreasi diterapkan pada materi & & Sangat baik \\
\hline
\end{tabular}

Berdasarkan hasil angket keterlaksanaan pembelajaran, ternyata pembelajaran menggunakan model PBL juga berpengaruh positif terhadap pembelajaran siswa di kelas. Hasil analisis menunjukkan persentase sebesar 91,5\% secara keseluruhan. Namun kendala pada proses pembelajaran di kelas masih ditemukan. Sebanyak 19,45 \% siswa masih kurang setuju terkait pernyataan "guru memberikan pertanyaan menarik di awal pembelajaran" karena biasanya pertanyaan tersebut dilontarkan kapan saja selama ada materi yang belum jelas. Pada pertanyaan, "apakah guru selalu menyimpulkan materi" ternyata masih ada $25 \%$ siswa menganggap bahwa pemberian kesimpulan bersama tidak selalu dilakukan di akhir pembelajaran. Jika dalam suatu pertemuan waktu untuk diskusi 
dan presentasi kurang, maka guru tidak sempat menyimpulkan materi tersebut.

\section{Hasil Tanggapan Guru}

Tanggapan guru terhadap pembelajaran dengan menerapkan model PBL berbantuan LKS Kreasi memberikan hasil yang positif. Tanggapan guru diperoleh dari hasil wawancara dengan guru biologi yang bersangkutan. Hasil wawancara dengan guru diperoleh tanggapan bahwa penerapan model pembelajaran PBL berbantuan LKS Kreasi berpengaruh positif terhadap proses $\mathrm{KBM}$ di kelas. Guru merasa siswa menjadi lebih aktif di dalam pembelajaran, aktif bertanya, dan aktif mengemukakan pendapat. Siswa bisa belajar secara mandiri meskipun guru hanya mendampingi saja. Ketika kegiatan diskusi, siswa terlibat kerja sama yang baik antar sesama anggota kelompok dan mampu menyelesaikan setiap kasus yang disajikan. Hasil pekerjaannya pun lengkap karena difasilitasi oleh LKS yang mampu mempermudah siswa memecahkan masalah.

Selain dari segi sikap, keterampilan saat praktikum pun terlihat begitu antusias. Peneliti memberikan inovasi praktikum yang diperoleh selama perkuliahan dan belum pernah dilakukan pada pembelajaran di kelas yaitu respirasi menggunakan ikan. Terlihat dari keantusiasan siswa ketika menyiapkan alat bahan, bekerja, sampai dengan bertanya halhal yang kurang jelas. Secara umum kesulitan yang ditemukan ketika pembelajaran ini diterapkan adalah mengenai alokasi waktunya. Guru menjelaskan bahwa dengan permasalahan yang banyak setiap pertemuannya, tidak cukup jika kasus diselesaikan hanya 1 jam pelajaran saja.

Saran yang diberikan oleh guru bahwa perlunya pemberlakuan model pembelajaran PBL di semua materi biologi sehingga tidak hanya berhasil pada salah satu materi saja. Alokasi waktu juga perlu diperhatikan mengingat untuk satu kali pertemuan tidaklah cukup untuk membahas kasus yang disajikan. Siswa juga harus selalu dikondisikan agar tetap tenang dalam berdiskusi.

\section{Keunggulan Model Pembelajaran PBL} berbantuan LKS Kreasi

Model pembelajaran Probem Based Learning merupakan model pembelajaran dengan menghadapkan siswa pada permasalahan-permasalahan dunia nyata. Sebelum belajar mempelajari suatu hal, mereka diharuskan mengidentifikasi suatu masalah, baik yang dihadapi secara nyata maupun telaah kasus (Wulandari, 2013). Keunggulan dari model PBL pada saat diterapkan di kelas antara lain: 1) Siswa menjadi aktif saat pembelajaran di kelas, 2) Siswa berpikir lebih kritis terhadap memecahkan permasalahan yang ada, dan 3) Siswa dapat mencari informasi dan pengetahuan secara luas.

\section{Keterbatasan dalam Menggunakan Model Pembelajaran PBL berbantuan LKS Kreasi}

Dalam pelaksanaan pembelajaran di kelas, PBL mampu menciptakan lingkungan belajar yang menyenangkan dan disukai siswa. Namun tidak selamanya pembelajaran di kelas berlangsung lancar. Keterbatasan penerapan model PBL di kelas disebabkan karena beberapa hal, yaitu: 1) Membutuhkan waktu yang cukup banyak sehingga guru perlu memperhitungkan waktu dalam setiap langkah yang ada dalam model PBL, 2) Pembelajaran hanya berpusat pada permasalahan yang diberikan, 3) Alokasi waktu yang digunakan untuk berdiskusi masih kurang, jika hanya diberikan satu jam pelajaran dan dilanjut 
dengan presentasi, dan 4) Guru harus bisa mengontrol diskusi siswa dalam kelompok secara adil.

\section{SIMPULAN DAN SARAN}

\section{Simpulan}

Berdasarkan hasil penelitian, dapat disimpulkan bahwa pembelajaran dengan menerapkan model PBL berbantuan LKS Kreasi Sistem Respirasi efektif meningkatkan hasil belajar siswa kelas XI MIA MAN 1 Magelang Tahun ajaran 2015/2016 pada materi sistem respirasi.

\section{Saran}

Saran yang dapat diberikan pada hasil penelitian ini yaitu perlu adanya penelitian lebih lanjut menggunakan model pembelajaran PBL berbantuan LKS Kreasi pada pokok bahasan maupun mata pelajaran yang lain

\section{DAFTAR PUSTAKA}

Arnyana, Ida. 2005. Pengaruh Penerapan PBL dipandu Strategi Kooperatif terhadap Kecakapan Berpikir Kritis Siswa SMA. Jurnal Pendidikan dan Pengajaran, IKIP Negeri Singaraja, 4:646-667

Damayanti. 2012. Pengembangan LKS dengan Pendekatan Inkuiri Terbimbing untuk Mengoptimalkan Kemampuan Berpikir Kritis Peserta Didik pada Materi Listrik Dinamis SMA 3 Purworejo. Jurnal Pendidikan, 4(2) : 115-132

Endarwati, H. 2011. Upaya Peningkatan Motivasi dan Keaktifan Berkomunikasi Siswa dengan Strategi Snowball Throwing pada Pembelajaran Biologi di Kelas X.3 SMA $\quad N \quad 1 \quad$ Sukoharjo.Skripsi. Surakarta: FKIP Universitas Sebelas Maret
Faturrohman. 2008. Pendidikan PBL untuk Meningkatkan Kemampuan Berpikir Kritis Siswa SD dalam Pembelajaran PKN. Majalah Ilmiah Pembelajaran, $1(4): 83$

Manahal, S, Endah Pujiningrum, dan Suyanto. 2007. Penerapan PBL dengan Strategi Kooperatif Model STAD pada Mata Pelajaran Sains untuk Meningkatkan Kemampuan Berpikir Kritis Siswa Kelas V MI Jenderal Sudirman. Jurnal Penelitian Kependidikan, 17(1): 33 - 48

Munandar, 2007. Guru Profesional Implementasi Kurikulum Tingkat Satuan Pendidikan dan Persiapan Menghadapi Sertifikasi Guru. Jakarta: Raja Grafindo Persada

Purnamaningrum, A. 2012.Peningkatan Kemampuan Berpikir Kreatif melalui Problem Based Learning (PBL) pada Pembelajaran Biologi Siswa Kelas X-10 SMA Negeri 3 Surakarta Tahun Pelajaran 2011/2012. Pendidikan Biologi, 4(3): 39 - 51

Putri, Yulian, Suratno, dan Nur Asyiah. 2015. Pengaruh Pembelajaran Inkuiri Terbimbing dengan Menggunakan Metode Eksperimen terhadap Aktivitas dan Hasil Belajar IPA Biologi Siswa Kelas VIII SMP Negeri 2 Maesan Bondowoso. Junal Penelitian Kependidikan, 4(2) : 163172

Prastowo, Andi. 2011. Panduan Kreatif Membuat Bahan Ajar Inovatif. Yogyakarta: Diva Press

Sandra, A, Isnaeni W., Prasetyo. 2012. Pengaruh Pendidikan PBL dalam Materi Pencemaran Lingkungan trehadap Kemampuan Analisis. Semarang: Unnes Journal of Biology Education, 1(3): 219 - 227 
Sanjya, W. 2007. Strategi Pembelajaran. Berorientasi Standar Proses Pendidikan. Jakarta: Kencana Prenada media Goup

Widodo dan Widayanti, Lusi. 2013. Peningkatan Aktivitas Belajar dan Hasil Belajar Siswa dengan Metode Problem Based Learning pada Siswa Kelas VII A MTs Negeri Donomulyo Kulon Progo Tahun
Pelajaran 2012/2013. Jurnal Pendidikan Indonesia, Vol XVII, (49): 32 - 35

Wulandari, Bekti dan Surjono, Herman. 2013. Pengaruh Problem-Based Learning terhadap Hasil Belajar ditinjau dari Motivasi Belajar PLC di SMK. Jurnal Pendidikan Vokasi, 3(2): 178191 